[Original]

\title{
High-Performance Liquid Chromatographic Analysis of Catecholamines by Native Fluorescence Measurements
}

\author{
Keiichi ARASHIDANI ${ }^{1}$ and Terumasa NAKAMURA ${ }^{2}$ \\ ${ }^{1}$ Division of Occupational Hygiene, School of Nursing and Technology, University of Occupational and \\ Environmental Health, Japan. Kitakyushu 807, Japan \\ ${ }^{2}$ Division of Clinical Chemistry, School of Nursing and Technology, University of Occupational and \\ Environmental Health, Japan. Kitakyushu 807, Japan
}

\begin{abstract}
Three kinds of catecholamines and a related compound, dopamine, norepinephrine, epinephrine and dopa were separated completely by high-performance liquid chromatography using a weak cation-exchange gel column and monitored by the native fluorescence measurements. The calibration curve for each catecholamine was a straight line within the range of $0.5 \mathrm{ng}$ to $300 \mathrm{ng}$. Recoveries of catecholamines in sample solutions were examined by varying the amount of activated alumina as an adsorbent and the concentration of acetic acid as an eluent. The use of $0.40 \mathrm{~g}$ of activated alumina and $2 \mathrm{ml}$ of $0.8 \mathrm{M}$ acetic acid resulted in the recoveries of nearly $85 \%$ for norepinephrine, epinephrine and dopamine with the coefficients of variation of nearly $2 \%$ and $68 \%$ for dopa with the coefficient of variation less than $5 \%$ from a urine solution containing a known amount of each catecholamine.
\end{abstract}

Key words: catecholamine, native fluorescence monitoring, HPLC.

(Received 20 August 1980)

\section{Introduction}

Recent investigations on the analysis of catecholamines in urine and biological fluids have been carried out by use of high-performance liquid chromatography (HPLC) (Mori, 1975; Higa et al., 1977; Imai et al., 1977; Molnár \& Horváth, 1977; Ueda et al., 1977; Imai \& Tamura, 1978; Mori, 1978; Anderson et al., 1980). Because of the complexity of the sample matrix, analytical procedures for catecholamines are usually composed of three steps, i.e., purification and concentration, chromatographic separation and detection. The purification and concentration of catecholamines is performed by an adsorption method using activated alumina (Von Euler \& Lishajko, 1959; Ueda et al., 1977), ionexchange resin (Seki, 1976) and aluminum hydroxide or a solvent extraction method (Yoshida et al., 1976). The chromatographic separation is carried out by HPLC using ion-exchange resin (Mori, 1975; Ueda et al., 1977; Okamoto et al., 1978) or bonded-phase column packings (Knox \& Jurand, 1976; Crombeen et al., 1978; Asmus \& Freed, 1979; Krstulovic et al., 1979). For the detection of catecholamines in the chromatographic effluent, several detection systems are employed, e.g., ultraviolet absorbance detection (Molnár \& Horváth, 1977), fluorescence detection with pre-column derivatization (Imai, 
1975) or post-column reaction (Von Euler \& Lishajko, 1961; Ueda et al., 1977; Okamoto et al., 1978), native fluorescence detection (Miyagawa et al., 1978; Krstulovic \& Powell, 1979) and electrochemical detection (Scratchley et al., 1979; Anderson et al., 1980). A large amount of literature on the chromatographic analysis of catecholamines have been published. Among them, the reported data on the recoveries of catecholamines in the adsorption-desorption step with alumina were not satisfactory (Von Euler \& Lishajko, 1959; Ueda et al., 1977). In addition, the use of native fluorescence measurements in the HPLC analysis of catecholamines has only been reported recently in a few works and any detailed information is unavailable.

In the present work, the authors examined the calibration curves for the three kinds of catecholamines and a related compound, dopamine, norepinephrine, epinephrine and dopa by use of native fluorescence measurements. The authors determined also the relationship between the recoveries of individual catecholamine investigated, the amount of activated alumina as an adsorbent and the concentration of acetic acid in the eluent.

\section{Experimental}

\section{Materials}

L-3, 4-dihydroxyphenylalanine (L-dopa; Tokyo-Kasei, Japan), Dopamine hydrochloride (DA; Wako, Japan), L-norepinephrine bitartrate (NE; Wako, Japan) and L-epinephrine bitartrate (E; Sigma, U.S.A.), were used without further purification. The individual catecholamine was dissolved in $0.1 \mathrm{M}$ hydrochloric acid and several mixed solutions with different concentrations of catecholamines were prepared. These sample solutions were stored in a freezer before use. A weak cation-exchange resin, Hitachi Gel 3011-C, 10$15 \mu \mathrm{m}$ (Hitachi, Japan), was used as a column-packing. Activated alumina (200 mesh) was obtained from Wako. All other chemicals were of analytical-reagent grade.

\section{Apparatus}

All chromatographic experiments were carried out on a high-performance liquid chromatograph (Hitachi 638) using a UV monitor (254 nm), a Hitachi 650-10 LC fluorescence spectrophotometer and a thermostated stainless-steel column of dimensions $250 \times 4 \mathrm{~mm}$ I. D. fed by a thermostated water bath (Haake F3, F. R. G.).

\section{Chromatographic conditions}

Hitachi Gel 3011-C was packed in the stainless-steel column by a pressurized slurry method. Eluent was composed of $0.1 \mathrm{M} \mathrm{KH}_{2} \mathrm{PO}_{4}-0.05 \% \mathrm{H}_{3} \mathrm{PO}_{4}$ and degassed by sonicating for $10 \mathrm{~min}$ before use. The column was operated at a flow rate of $1.5 \mathrm{ml} \cdot \mathrm{min}^{-1}$ and the column temperature of $20,30,40$ or $50^{\circ} \mathrm{C}$. Native fluorescence measurements were carried out with an excitation wavelength of $275 \mathrm{~nm}$ and an emission wavelength of 325 nm. Some chromatographic parameters, retention time, peak height and peak area, 
were printed by use of a computing integrator equipped with a Hitachi 638 Liquid Chromatograph.

\section{Recoveries of catecholamines in standard aqueous solution}

Sample solutions were prepared by mixing $5 \mathrm{ml}$ of dilute ammonia water with $\mathrm{pH} 8.5$ and $1 \mathrm{ml}$ of a standard solution containing $1 \mu \mathrm{g}$ of each catecholamine per $\mathrm{ml}$. The $\mathrm{pH}$ of the sample solution was then adjusted again to 8.5. All of the sample solution was passed through a glass column $(9 \mathrm{~mm} \mathrm{I.D.} \times 180 \mathrm{~mm})$ containing $0.10 \mathrm{~g}$ of activated alumina and washed with $10-15 \mathrm{ml}$ of distilled water. The catecholamines adsorbed in the alumina were eluted with $2 \mathrm{ml}$ of $0.6 \mathrm{M}$ acetic acid and the effluent was collected in a test tube. Similar procedures were carried out for other sample solutions except for the variable amounts of activated alumina in the glass column from $0.10 \mathrm{~g}$ to $1.50 \mathrm{~g}$. Ten $\mu$ l of the effluent was applied to the liquid chromatograph and the amount of each catecholamine was determined by native fluorescence measurements. The recoveries of catecholamines were obtained by comparing the chromatographic peak areas or heights with those for the standard solution.

The effect of the composition of the solvent on the elution of the catecholamines adsorbed on alumina was examined by the same method as described above except for the use of $0.40 \mathrm{~g}$ of activated alumina and a series of acetic acid solutions with different concentrations from $0.2 \mathrm{M}$ to $1.2 \mathrm{M}$.

\section{Recoveries of catecholamines in urine}

One $\mathrm{ml}$ of $6 \mathrm{M} \mathrm{HCl}$ was added to $50 \mathrm{ml}$ of urine sample and the conjugated catecholamines were acid-hydrolyzed in boiling water for $20 \mathrm{~min}$. After cooling and adding $0.25 \mathrm{~g}$ of disodium ethylenediaminetetraacetate, the urine sample was adjusted to $\mathrm{pH} 8.5$ with $7 \%$ ammonia water. Then, the solution was immediately passed through a glass column containing $0.40 \mathrm{~g}$ of activated alumina. Sample solutions were prepared by mixing $5 \mathrm{ml}$ of the treated urine solution and $1 \mathrm{ml}$ of a standard solution containing $1 \mu \mathrm{g}$ of each catecholamine per $\mathrm{ml}$ and then the $\mathrm{pH}$ of the solution was adjusted to 8.5. All of each sample solution was passed through a glass columm ( $9 \mathrm{~mm} \mathrm{I.D.} \times 180 \mathrm{~mm}$ ) containing $0.40 \mathrm{~g}$ of activated alumina and washed with $10-15 \mathrm{ml}$ of distilled water. The catecholamines adsorbed on alumina was eluted with $2 \mathrm{ml}$ of $0.8 \mathrm{M}$ acetic acid and the effluent was collected in a test tube. The separation and determination of each catecholamine in the effluent was carried out by the same method as described above.

\section{Results and Discussion}

\section{Chromatographic separation of catecholamines}

Three kinds of catecholamines and a related compound, NE, E, DA and L-dopa, were separated completely by the HPLC system used in the present work and the retention time 
decreased for all samples with increasing column temperatures from $20^{\circ} \mathrm{C}$ to $50^{\circ} \mathrm{C}$ as shown in Fig. 1. A typical chromatogram for a mixed solution of catecholamines is given in Fig. 2, which shows a well-resolved peak for each component within $20 \mathrm{~min}$ at the column temperature of $50^{\circ} \mathrm{C}$. These results suggest that the present chromatographic system is applicable to the determination of catecholamines.

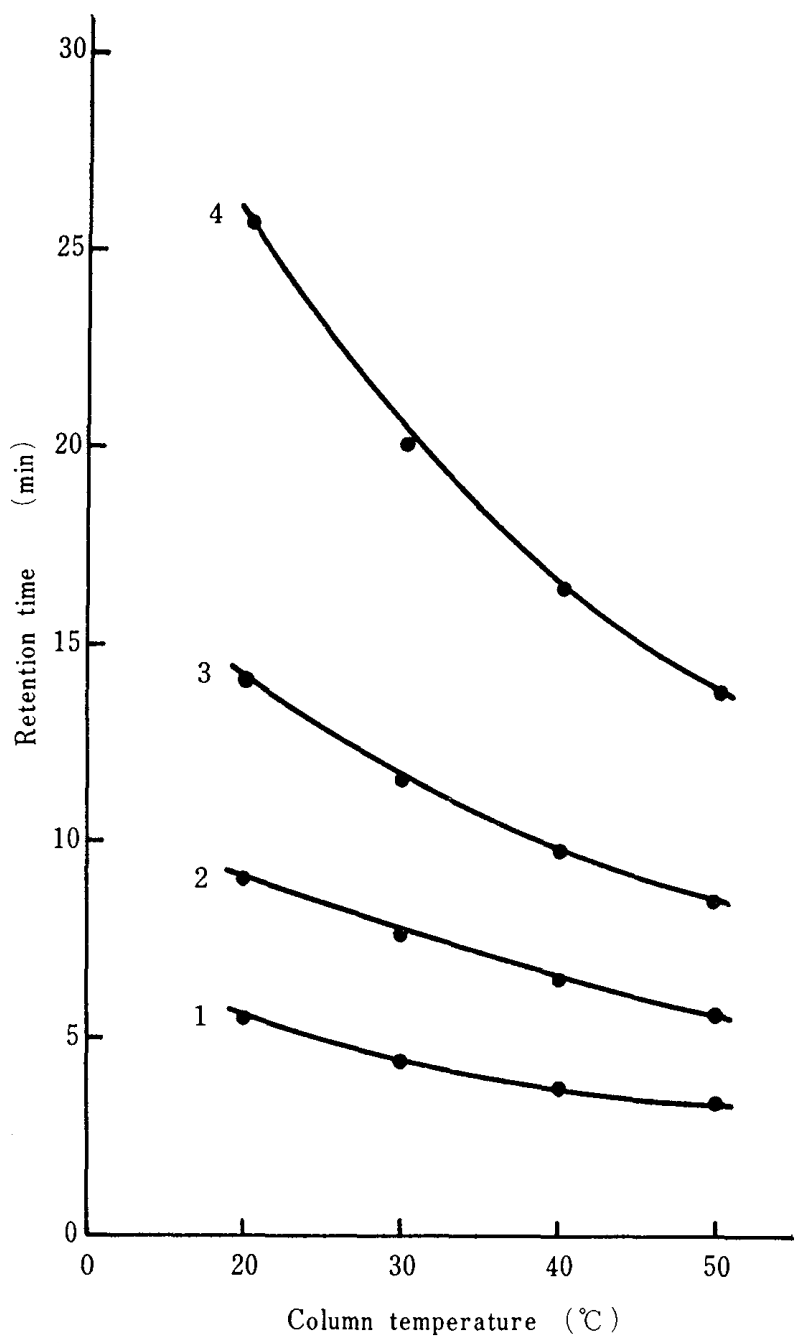

Fig. 1.

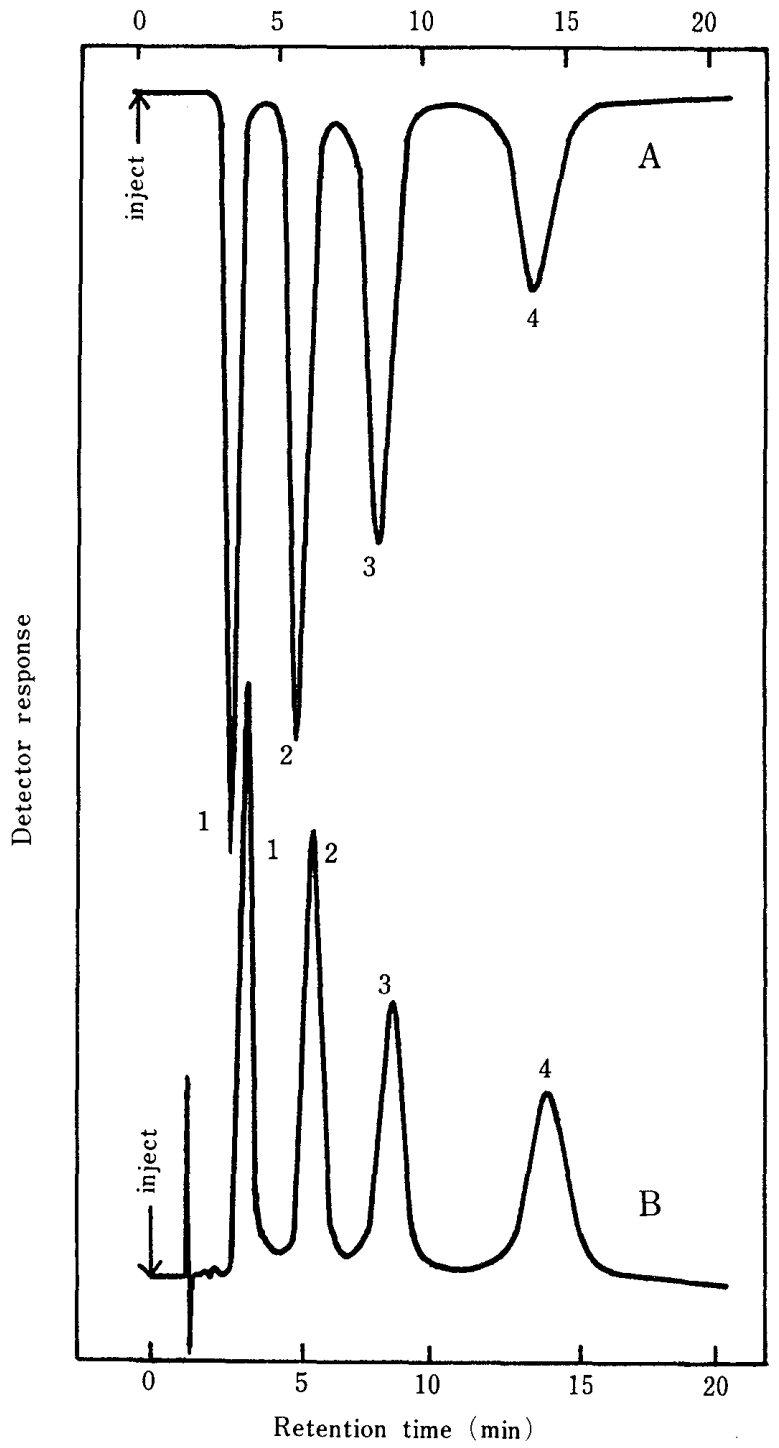

Fig. 2 .

Fig. 1. Relationship between column temperature and retention times of catecholamines. Eluent: $0.1 \mathrm{M} \mathrm{KH}_{2} \mathrm{PO}_{4}$. Flow rate: $1.5 \mathrm{ml} \cdot \mathrm{min}^{-1}$. Pressure: $46 \mathrm{~kg} \cdot \mathrm{cm}^{-2}$. Detection: native fluorescence measurement (Ex. $275 \mathrm{~nm}$, Em. $325 \mathrm{~nm}$ ). Sample: $1=\mathrm{L}$-dopa, $2=\mathrm{NE}, 3=\mathrm{E}, 4=\mathrm{DA}$.

Fig. 2. A typical chromatogram of catecholamines. A: native fluorescence (Ex, $275 \mathrm{~nm}$, Em. $325 \mathrm{~nm})$. B: UV $(254 \mathrm{~nm})$. Column: Hitachi Gel 3011-C, $250 \times 4 \mathrm{~mm}$ I. D. Temperature: $50^{\circ} \mathrm{C}$. Other chromatographic conditions same as in Fig. 1. Sample: $1=\mathrm{L}$-dopa $(5 \mu \mathrm{g}), 2=\mathrm{NE}(5 \mu \mathrm{g}), 3=\mathrm{E}(5 \mu \mathrm{g}), 4=\mathrm{DA}(5 \mu \mathrm{g})$. 


\section{Calibration curves for catecholamines}

Although the native fluorescence measurement with excitation at $275 \mathrm{~nm}$ and emission at $325 \mathrm{~nm}$ is not exclusively selective for catecholamines, it provides a high-sensitive monitoring device (Krstulovic \& Powell, 1979; Scratchley et al., 1979). Fig. 3 gives the relationship between the amount of each catecholamine injected into the liquid chromatograph and the corresponding peak area monitored by native fluorescence measurements. The calibration curve for each catecholamine was confirmed to be a straight line with the characteristic slope of it within the range of $0.5 \mathrm{ng}$ to $300 \mathrm{ng}$. Similar relationships were obtained by use of peak heights instead of peak areas. A clear peak was obtained for each catecholamines even as small as the injected amount of $0.5 \mathrm{ng}$ for L-dopa, NE and $\mathrm{E}$, and $1.0 \mathrm{ng}$ for $\mathrm{DA}$, respectively. These results indicate that the detection of catecholamines by use of native fluorescence give satisfactorily reliable data as a monitor of HPLC.

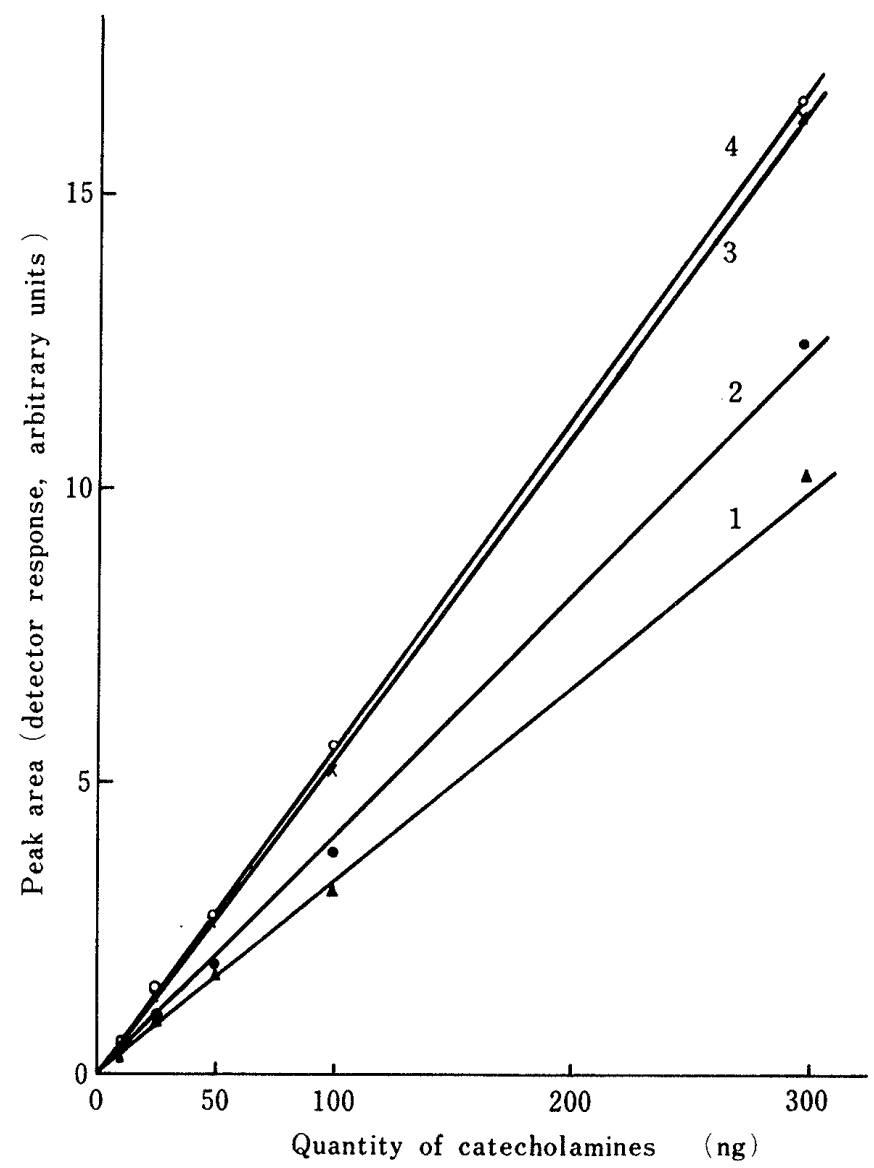

Fig. 3. Calibration curves for catecholamines by native fluorescence measurements. Chromatographic conditions same as in Fig. 2. Sample: 1=DA, 2=L-dopa, $3=\mathrm{NE}, \quad 4=\mathrm{E}$. 
Effect of the amount of activated alumina as an adsorbent and the concentration of acetic acid as an eluent on the recoveries of catecholamines

Fig. 4 gives the recoveries of catecholamines by use of different amounts of activated alumina as the adsorbent and $2 \mathrm{ml}$ of $0.6 \mathrm{M}$ acetic acid as the eluent. For the different kinds of catecholamines investigated, plateaus in recoveries were obtained within the range of $0.25 \mathrm{~g}$ to $0.50 \mathrm{~g}$ of activated alumina although the recovery of L-dopa was considerably smaller than those of NE, E and DA. From these results it is expected that the use of $0.40 \mathrm{~g}$ of activated alumina provides a maximal and constant recovery for each catecholamine.

Then, the recoveries of catecholamines from $0.40 \mathrm{~g}$ of activated alumina were examined for a series of eluents with different concentrations of acetic acid. The results are given in Fig. 5. The recoveries of $\mathrm{E}, \mathrm{NE}$ and $\mathrm{DA}$ are practically constant values, near $80 \%$ for the eluents with concentration of acetic acid from $0.3 \mathrm{M}$ to $1.2 \mathrm{M}$. On the other hand, the recovery of L-dopa increased with the increasing concentration of acetic acid and reached a plateau of nearly $60 \%$ at the eluent with $0.8 \mathrm{M}$ acetic acid.

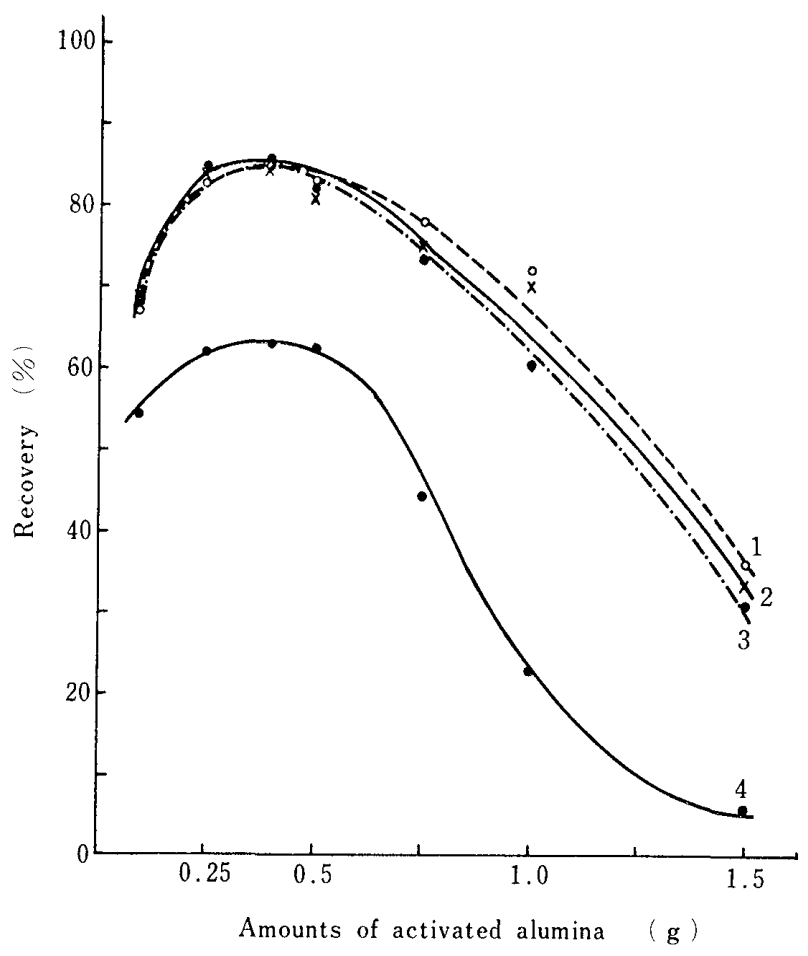

Fig. 4.

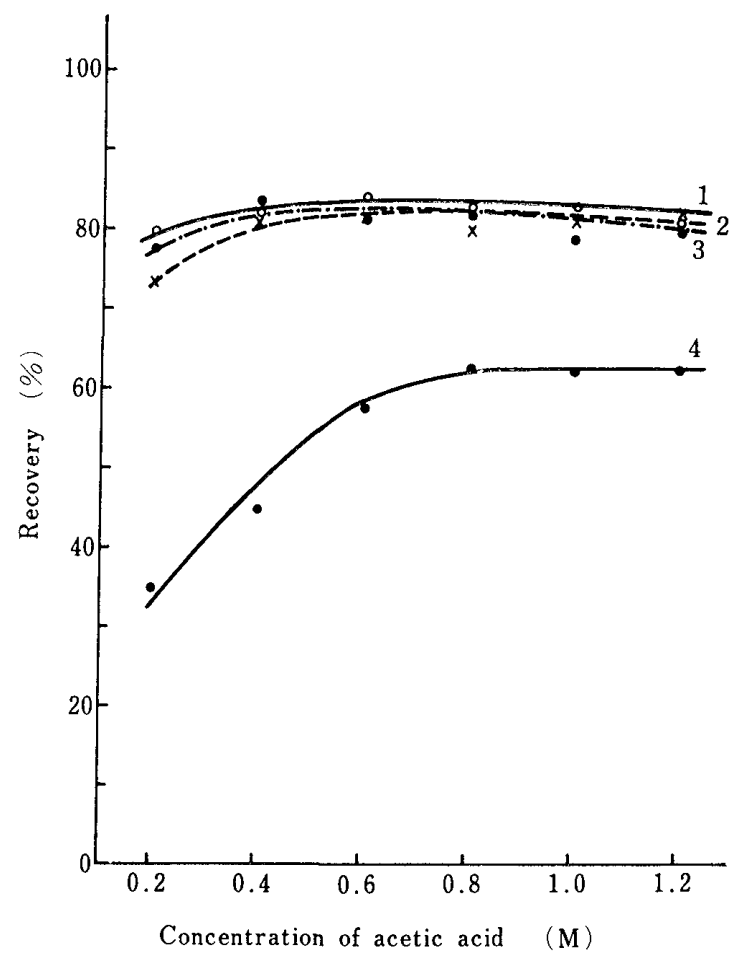

Fig. 5.

Fig. 4. Relationship between recoveries of catecholamines and amounts of activated alumina. Eluent: $0.6 \mathrm{M}$ acetic acid $(2 \mathrm{ml})$. Sample: $1=\mathrm{E}(1 \mu \mathrm{g}), 2=\mathrm{NE}(1$ $\mu \mathrm{g}), 3=\mathrm{DA}(1 \mu \mathrm{g}), 4=\mathrm{L}$-dopa $(1 \mu \mathrm{g})$.

Fig. 5. Relationship between recoveries of catecholamines and concentration of acetic acid. Activated alumina: $0.40 \mathrm{~g}$. Volume of eluent: $2 \mathrm{ml}$. Sample: $1=\mathrm{E}(1 \mu \mathrm{g})$, $2=\mathrm{DA}(1 \mu \mathrm{g}), 3=\mathrm{NE}(1 \mu \mathrm{g}), 4=\mathrm{L}-\mathrm{dopa}(1 \mu \mathrm{g})$. 
Table 1. Recovery of catecholamine from urine and its retention time in HPLC analysis

\begin{tabular}{|c|c|c|c|c|c|c|c|c|c|c|c|c|}
\hline \multirow{3}{*}{ Run } & \multicolumn{3}{|c|}{ L-Dopa } & \multicolumn{3}{|c|}{ Norepinephrine } & \multicolumn{3}{|c|}{ Epinephrine } & \multicolumn{3}{|c|}{ Dopamine } \\
\hline & \multicolumn{2}{|c|}{ Recovery } & \multirow{2}{*}{ R. T. } & \multicolumn{2}{|c|}{ Recovery } & \multirow{2}{*}{ R.T. } & \multicolumn{2}{|c|}{ Recovery } & \multirow{2}{*}{ R. T. } & \multicolumn{2}{|c|}{ Recovery } & \multirow{2}{*}{ R. T. } \\
\hline & A. & $\mathrm{H}$. & & A. & $\mathrm{H}$. & & A. & H. & & A. & $\mathrm{H}$. & \\
\hline 1 & 62.0 & 63.0 & 3.40 & 83.0 & 81.5 & 6.61 & 81.5 & 81.0 & 9.24 & 88.0 & 84.0 & 14.13 \\
\hline 2 & 69.0 & 70.0 & 3.40 & 85.5 & 85.5 & 6. 10 & 86.0 & 86.5 & 9.21 & 85.5 & 85.5 & 14.09 \\
\hline 3 & 70.5 & 71.0 & 3.41 & 86.0 & 85.5 & 6.16 & 84.0 & 86.0 & 9.25 & 90.5 & 85.5 & 14.16 \\
\hline 4 & 67.0 & 68.0 & 3.42 & 85.8 & 86.0 & 6.16 & 84.5 & 87.0 & 9.29 & 84.0 & 85.5 & 14.29 \\
\hline 5 & 70.5 & 70.5 & 3.14 & 87.0 & 86.0 & 6.10 & 85.5 & 87.0 & 9.17 & 87.5 & 85.5 & 14.14 \\
\hline 6 & 66.5 & 67.0 & 3.38 & 87.0 & 85.5 & 6.09 & 84.5 & 87.0 & 9.20 & 88.5 & 89.0 & 14.24 \\
\hline Mean & 67.6 & 68.3 & 3.40 & 85.7 & 84.9 & 6.13 & 84.3 & 85.8 & 9.23 & 87.3 & 85.8 & 14.18 \\
\hline C. V. & 4. 76 & 4.39 & 0.29 & 1.72 & 2.02 & 0.49 & 1.87 & 2.75 & 0.43 & 2.62 & 1.94 & 0.54 \\
\hline
\end{tabular}

A. : Peak area measurement R. T. : Retention time (min)
H. : Peak height measurement

C. V. : Coefficient of variation

On the basis of these results, it is concluded that the use of $0.40 \mathrm{~g}$ of activated alumina and $2 \mathrm{ml}$ of $0.8 \mathrm{M}$ acetic acid is a reasonable experimental condition for the adsorption of catecholamines from the sample solution and the desorption of them from the activated alumina, respectively.

\section{Recoveries of catecholamines from urine}

In order to confirm the practical applicability of the present method to urine samples, $1 \mu \mathrm{g}$ of each catecholamine was added to the pre-treated urine solution and the recovery was determined. The results are given in Table 1. Retention time for each catecholamine in the chromatographic separation is also listed in the same table.

Although the recoveries of the different kinds of catecholamines investigated are a little higher than those expected from the data in Fig. 5, this data seems to be reliable judging from the coefficients of variation as small as nearly $2 \%$ for $\mathrm{NE}, \mathrm{E}$ and DA, and less than $5 \%$ for L-dopa. The reproducibility in retention time for each catecholamine by HPLC analysis was also satisfactory.

In conclusion, the present method was confirmed to be a useful one for the sample preparation followed by a HPLC analysis of catecholamines. However, there are many components in the extracted solution from biological samples, some of which may be detected by the native fluorescence measurements under the conditions employed here. For the quantitative analysis of catecholamines and related compounds in biological samples, it is required that some HPLC system with higher resolution efficiency is combined with the present method for the sample preparation and detection, 


\section{References}

Anderson, G. M., Batter, D. K., Young, J. G. et al. (1980): Simplified liquid chromatographicelectrochemical determination of norepinephrine and dopamine in the rat brain. J. Chromatogr., 181: 453-455.

Asmus, P. A. \& Freed, C. R. (1979): Reversed-phase high-performance iiquid chromatography of catecholamines and their congeners with simple acid as ion-pairing reagents. J. Chromatogr., 169: 219-311.

Crombeen, J. P., Kraak, L. C. \& Poppe, H. (1978): Reversed-phase systems for the analysis of catecholamines and related compounds by high-perfomance liquid chromatography. J. Chromatogr., 167: $219-230$.

Higa, S., Suzuki, T., Hayashi, A. et al. (1977): Isolation of catecholamines in biological fluids by boric acid gel. Anal. Biochem., 77: 18-24.

Imai, K. (1975): Fluorimetric assay of dopamine, norepinephrine and their 3-O-methyl metabolites by using fluorescamine. J. Chromatogr., 105: 135-140.

Imaj, K., Tsukamoto, M. \& Tamura, Z. (1977): High-performance liquid chromatographic assay of rat-brain dopamine and norepinephrine. J. Chromatogr., 137: 357-362.

Imai, K. \& Tamura, Z. (1978): Liquid chromatographic determination of urinary dopamine and norepinephrine as fluorescamine derivatives. Clin. Chim. Acta, 85: 1-6.

Knox, J. H. \& Jurand, J. (1976): Separation of catecholamines and their metabolites by adsorption, ion-pair and soap chromatography. J. Chromatogr., 125: 89-101.

Krstulovic, A. M. \& Powell, A. M. (1979): Use of native fluorescence measurements and stoppedflow scanning technique in the high-performance liquid chromatographic analysis of catecholamines and related compounds. J. Chromatogr., 171: 345-356.

Krstulovic, A. M., Zakaria, M., Lohse, K. et al. (1979): Diagnosis of neural crest tumors by reversed-phase high-performance liquid chromatographic determination of urinary catecholamine metabolites. J. Chromatogr., 186: 733-748.

Miyagawa, T., Hasegawa, K., Takahashi, F. et al. (1978): Analysis of catecholamines by native fluorescence measurement. Jap. J. Clin. Pathol., 26: 273. (in Japanese)

Molnár, I. \& Horváth, C. (1977): Rapid separation of urinary acid by high-performance liquid chromatography. J. Chromatogr., 143: 391 400.

Mori, K. (1975): Analysis of catecholamines by high-speed liquid chromatography (Part III) Separation of urinary adrenaline, noradrenaline, metanephrine and normetanephrine in man. Jap. J. Ind. Health, 17: 116 117. (in Japanese)

Mori, K. (1978): Automated measurement of catecholamines in urine by high-speed liquid chromatography with fluorometric reaction detection. Ind. Health, 16: 41-44.

Okamoto, K., Ishida, Y. \& Asai, K. (1978): Separation and detection of small amounts of catecholamines by high-performance liquid chromatography. J. Chromatogr., 167: 205-217.

Scratchley, G. A., Masoud, A. N., Stohs, S. J. et al. (1979): High-performance liquid chromatographic separation detection of catecholamines and related compounds. J. Chromatogr., 169: 313-319.

Seki, T. (1976): Chromatographic separation of catecholamines on a weakly acid ion-exchange resin using a borate-containing eluent. J. Chromatogr., 124: 411-414.

Ueda, E., Yoshida, N., Nishimura, K. et al. (1977): A semi-automated measurement of urinary catecholamines using high-speed ion-exchange column chromatography. Clin. Chim. Acta, 80: 447-453.

Von Euler, U. S. \& Lishajko, F. (1959): The estimation of catechol amines in urine. Acta Physiol. Scand., 45: 122-132. 
Von Euler, U. S. \& Lishajko, F. (1961): Improved technique for the fluorimetric estimation of catecholamines. Acta Physiol. Scand., 51: 348-356.

Yoshida, A., Yoshioka, M., Tanimura, T. et al. (1976): Determination of vanilmandelic acid and homovanillic acid in urine by high-speed liquid chromatography. J. Chromatogr., 116: 240-243.

高速液体クロマトグラフィ一・自然螢光法を用いたカテコールアミンの分析

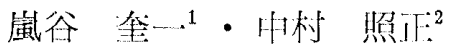

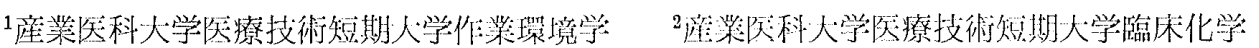

要 旨：カテコールアミン扰どその関連物質，ドーパミン，ノルエピネフリンエエピネフリンお よびドーパ，弱陽イオン交撸樹脂を用いた高速液体クロマトグラフィーにて分離し，自然 螢光測定によって検山した，自然螢光测定より得られた各々のカテコールアミンの検量線

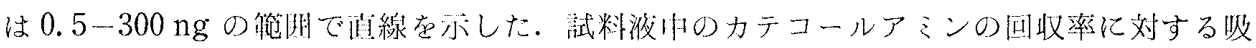

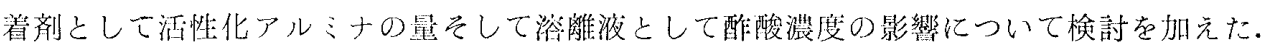

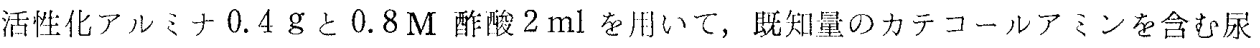
中からの回收率之変動係数を求めた。ノルエピネフリン，エピネフリン㧍よびドーパミン の回収率と変動係数はほぼ85\%と2\%，ドーパのそれらは活ば68\%と5\%以下であった。

J. UOEH（産業医大誌)，2（4)：439-447(1980) 